\title{
Aggressive and Delinquent Behavior among High Risk Youth in Malaysia
}

\author{
Haslinda Abdullah ${ }^{1,2}$, Adriana Ortega ${ }^{1}$, Nobaya Ahmad $^{3} \&$ Syamsyihana Ghazali $^{3}$ \\ ${ }^{1}$ Institute for Social Science Studies (IPSAS), Universiti Putra Malaysia, Serdang, Selangor, Malaysia \\ ${ }^{2}$ Research Innovation. Faculty of Human Ecology, Universiti Putra Malaysia, Malaysia \\ ${ }^{3}$ Department of Social \& Development, Universiti Putra Malaysia, Serdang, Selangor, Malaysia \\ Correspondence: Adriana Ortega, Institute for Social Science Studies (IPSAS), Universiti Putra Malaysia, \\ Serdang, 43400 Selangor, Malaysia. Tel: 60-3-8947-1897. E-mail: adryortegaro@gmail.com
}

Received: November 9, 2014 Accepted: April 14, 2015 Online Published: June 13, 2015

doi:10.5539/ass.v11n16p62 URL: http://dx.doi.org/10.5539/ass.v11n16p62

\begin{abstract}
Currently there is an alarming increase on youth involved in delinquency and criminal action in urban and sub urban areas of Malaysia. This paper aimed to measure the level of aggressive and delinquent behaviour, identify the most common delinquent behaviours, and examine the associations of aggressive and delinquent behaviour with demographic factors and individual characteristics among a sample of high risk Malaysian youth. The data used in this paper was obtained from a larger study designed to identify patterns of delinquent behaviour among teenagers and young people (15-40 years old). The results indicate that although the sample consisted of high risk youth, participants scored low in delinquent behaviour and moderate in aggressive behaviour. The findings also show significant associations between delinquent behaviour levels with both age and ethnicity; but no significant associations with gender or religion. Results indicate that common perceptions about at-risk youth may run contrary to reality; despite being at-risk, the respondents displayed lower-than-expected levels of delinquency, and moderate aggressive behaviour.
\end{abstract}

Keywords: aggressive behaviour, delinquent behaviour, risk, urban youth

\section{Introduction}

Aggressive behaviour is one of the components of the conduct disorder that consists of physical or verbal behaviour that harm or threaten with harming others (DSM-IV); and it can be self-protective or self-destructive (Ferris \& Grisso, 1996). There are different types of aggressive behaviour; but commonly aggression categorized aggressive behaviour in terms of its function (Dodge \& Schwartz, 1997; Feshbach, 1971). Thus the most predominant and influential classification is hostile aggression and instrumental aggression (Feshbach, 1970). Hostile aggression also called affective aggression; it is in nature uncontrolled, emotionally charged physical or verbal violence that causes physical injury or pain on the victim (Atkins \& Stoff, 1993). In contrast, instrumental aggression or predatory aggressive behaviour is controlled and purposeful non-physical violence that damage the victim's relationships with others and/or social (Meloy, 1988; Crick \& Grotpeter, 1995; Atkins \& Stoff, 1993; Dodge, 1991; Feshbach, 1970). Research on children and adolescent aggressive behaviour have reported that while boys tend to engage in physical aggression (hostile aggression) girls are more likely to express aggression in a relational sense (instrumental aggression). That is girls tend to use their relationships to inflict harm, manipulate peers to harm others' feelings of social acceptance (e.g. social exclusion, rumours and slander) (Miller-Ott \& Kelly, 2013; Basow, Cahill, Phelan, Longshore, \& McGillicuddy-DeLisi, 2007; Hadley, 2003).

According to Liu (2005) studies have shown that childhood and adolescent aggressive behaviour is a strong predictor of delinquency (Farrington, 2001; Moffitt, 1993). While aggressive behaviour has been described as part and parcel of a behavioural disorder; delinquency is a legal concept used to describe diverse antisocial actions including theft, burglary, robbery, vandalism, drug use, and aggressive behaviour (Farrington, 1987). Delinquency is often used as a synonymous of antisocial behaviour which include lying, cheating, stealing, and committing antisocial acts, etc. (Achenbach, 1991; Achenbach \& Edelbrock, 1983). In this article, delinquency is specifically used describe antisocial behaviours that are considered unlawful in Malaysia (e.g. using drugs; damaging public properties; hitting or physical assaulting others, driving without a license; carrying weapon; 
drinking alcohol; engaging in premarital sex, etc.)

Youth delinquency is also refers to as juvenile delinquency, juvenile offending or youth crime; and it has been defined as the participation in illegal behaviour by young people under the statutory age of majority (Siegel \& Welsh, 2005), which in most countries is 19 years old. Youth delinquent actions can range from status offenses (such as underage smoking), to property crimes and violent crimes. Most delinquent acts committed by adolescents tend to be non-violent (Moffitt, 2006). Some of these actions would be normally charged as a crime if the offender is an adult (e.g. over 19 years old). Nonetheless, depending on the type and severity of the delinquent offense/action it is possible for minors to be charged as adults. Authors suggest that juvenile delinquency can be considered normative teen behaviour and that most young people commit non-violent crimes during adolescence (Steinberg, 2008; Moffitt, 2006). However, juvenile repeated and persistent delinquency actions and/or violent crimes can turn into violent offenses and the offenders would start exhibiting antisocial behaviour (Moffitt, 2006). Thus these young people who are involved in repeated and persistent delinquency or criminal actions can be considered as youth at risk

Previous research has identified two types of antisocial behaviour namely early-onset type and late-onset type (Schulenberg \& Zarrett, 2006). According to the work by Schulenberg and Zarrett (2006) early-onset antisocial behaviour starts around age 11 and could lead to chronic juvenile delinquency in adolescence and adulthood. It has been linked to a range of interacting factors such as parent-child hostility, poor parenting practices, and peer deviance, to community structure and social support (Buehler, 2006; Tolan, Gorman-Smith, \& Henry, 2003). And it has been reported that young people who have display early-onset antisocial behaviour tend to exhibit also poor impulse control, not thinking beyond their current state/situation and behave aggressively (Monahan, Cauffman, \& Steinberg, 2009). On the other hand, late-onset antisocial behaviour starts after puberty, and it seems to be connected to the combination of hormonal and social changes that take place during adolescence; also it has been linked to need for autonomy, and the decrease of adult supervision experienced by teenagers (Schulenberg \& Zarrett, 2006).

Similarly, youth offenders have also been categorized into two main types by Moffitt (2006); these two types are the age specific and the repetitive offenders. According to Moffitt (2006) repetitive offenders start showing antisocial or criminal behaviour in childhood and adolescence (e.g. displaying early-onset antisocial behaviour) and their antisocial or criminal behaviour continues into adulthood. While for age specific offenders displaying antisocial or criminal behaviour begins and ends during adolescence.

Earlier studies have indicate that the prevalence of youth delinquency increases during puberty, peaks in middle adolescence, and steadily declines as young people transition into adulthood (McCord, Widom, \& Crowell, 2001; Nagin, Farrington, \& Moffitt, 1995; Loeber, Stouthamer-Loeber, Van Kammen, \& Farrington, 1991). In line with early findings, Moffitt (2006) and Schulenberg and Zarrett, (2006) have indicated that adolescence have a tendency to show some form of antisocial, aggressive or delinquent behaviour, but this tendency decrease as adolescence grow up and enter in adulthood. Thus, one could argue that normally antisocial and delinquency offenses during adolescence are temporarily and part and parcel of the adolescent period of adjustment. Nonetheless, research shows that whether they are age specific or repeat offender, they will exhibit more mental health, substance abuse, and finance problems, than those who did not delinquent or engage in risk behaviour (Aguilar, Sroufe, Egeland, \& Carlson, 2000).

Therefore, efforts should be made towards reducing the impact of risk factors for youth delinquency. Amongst the risk factors for youth or juvenile delinquency the most commonly reported are demographic characteristics (e.g. age, gender, race); as well as aggression; deviant peer association, antisocial attitudes and behaviour; low intelligence (Bartol \& Bartol, 2009; Farrington, 2002; Lynam, Miller, Vachon, Loeber, \& Stouthamer-Loeber, 2009). Also some individual characteristics commonly associated with youth delinquency are impulsiveness, aggression, lack of empathy, lack of emotional control and cruel behaviour are risk factors associated with youth delinquency (Farrington, Loeber, Jolliffe, \& Pardini, 2008; Piquero, Farrington, \& Blumstein, 2007; Loeber, Green, \& Lahey, 2003).

According to previous studies lack of close or positive parents' involvement in children lives is a common risk factor for early-onset antisocial behaviour (Patterson, DeBaryshe, \& Ramsey, 1989). Some authors have suggested that children antisocial behaviour and delinquency actions might be a way for children to seek for attention (Brown, Mounts, Lamborn, \& Steinberg, 1993; Collins, Noble, Poynting, \& Tabar, 2000). Thus parents' reaction or lack of it would contribute to a vicious cycle by increasing vulnerability for negative peer influences and reinforce antisocial behaviour. Furthermore, studies have shown that adolescents whose parents know where they are and what they are doing are less likely to engage in delinquent acts (Laird, Pettit, Bates, \& Dodge, 2003) 
or to associate with deviant peers (Lloyd \& Anthony, 2003).

According to Collins and colleagues (2000) children and adolescents tend to associate themselves with others that are similar to them, for example children and youth would associate themselves with those who have of similar school performance, involvement, coping and adjustment strategies; and prosocial and/or antisocial tendencies. Earlier studies show that during childhood, antisocial adolescents tended to interact with other children that also exhibit antisocial behaviour; thus their antisocial behaviour was reinforced (Dishion, McCord, \& Poulin, 1999; Hartup \& Stevens, 1999; Vitaro, Tremblay, Kerr, Pagani, \& Bukowski, 1997). Also, there is research evidence to indicate antisocial behaviour in children and teenagers paired with ineffective parenting are associated with delinquent behaviour and involvement in deviant peer groups or gangs (Simons, Chao, Conger \& Elder, 2001; Tolan, Gorman-Smith, \& Henry, 2003). Similarly, and early study in Malaysia indicates that the tendency of parents of portraying a loose attitude in regards to traditional family values and changes in family day care patterns has resulted in parents no longer being role models for their children (Haslinda Abdullah, Sarjit Gill, Nobaya, \& Ahmad, et al., 2009) and as results Malaysian adolescents and youth turn to their peers for guidance, support and understanding while drifting apart from their parents and families. Thus changes in parental attitudes and style and reliance on peers have important impact on individual personality and social development, particularly in shaping the lifestyle of youth; and it might be considered as important risk factors for youth delinquency in Malaysia.

Family socioeconomic status can also influence the development of antisocial behaviour in children and adolescents. So, poverty, low social economic status, paired with low parental monitoring, harsh discipline and deviant peer groups have been associated with juvenile delinquency (Farrington, 2002; Aaron \& Dallaire, 2010; Cauffman, Piquero, Kimonis, Steinberg, \& Chassin, 2007; Steinberg, 2008). Although race is another factor that has been found repeatedly associated with delinquency in USA, Canada and Australia (Leiber \& Johnson, 2008; Lynam Miller, Vachon, Loeber, \& Stouthamer-Loeber 2009; Yessine \& Bonta, 2009; Livingston, Stewart, Allard, \& Ogilvie, 2008; Marshall, 2006), the racial minorities youth referred in those studies belonged to social disadvantage groups. Thus, the relation between delinquency and race may be explained by contextual risk variables (Holmes et al., 2009). Furthermore, Mannes and colleagues (2005) found that while youth from low-income families and/or ethnic minorities are more likely to be involved in criminal, delinquency or in antisocial behaviour, youth with low development assets (relationships, skills, and values) were four times more likely to engage in antisocial behaviour regardless their economic status families (Mannes, Roehlkepartain, \& Benson, 2005).

Gender is another demographic variable that is considered as a risk factor for delinquency. Research shows that boys who had early antisocial influences are more likely to become delinquents than girls (Dodge, Coie, \& Lynam, 2006; Shader, 2003; Sprott \& Doob, 2003; Bor, Najman, O'Callaghan, Williams, \& Anstey, 2001; Wan Ghazali, 2000). In Malaysia, Siti Hadidah (1992); Raman (1999) and Wan Ghazali (2000) reported that delinquency and involvement in antisocial behaviour are more prevalent among boys than among girls. However, these differences may vary depending on the type of delinquency behaviour or criminal offense. According to Latimer and colleagues (2003) the prevalence of violent and sexual aggression is higher among young male offenders than young female violent and sexual offenders; however, while there is no gender differences in property crimes, and drug-trafficking. Some authors argue that being tough, aggressive and competitive is how boys are taught to reaffirm and express their masculinity (Eadie \& Morley 2003); therefore young men are more likely to engage in antisocial and criminal behaviour than young women (Walklate, 2003; Brown, 1998). Nonetheless, nowadays gap between gender differences in youth delinquency seems to be getting smaller (Steffensmeier, Schawrtz, Zhong, \& Ackerman, 2005; Cauffman, Farruggia, \& Goldweber, 2008).

Early onset of aggressive behaviour and oppositional defiant behaviour in childhood are among the strongest risk or predicting factor associated with of antisocial behaviour and youth crime (Day \& Wanklyn, 2012; Robins 1966; Thornberry, Hulzinga, \& Loeber, 1995; Tolan \& Thomas, 1995; Farrington, 1994; Moffitt, 1993). According to Campbell (1995) aggressive behaviour exhibit by preschool children could continue to middle school and escalate into antisocial and/or criminal behaviour during adolescent. And in line with Campbell (1995), Wasserman \& Miller (1998) reported that the most serious and violent offenders had history of childhood misbehaviour and physical aggression. Similarly recent studies indicate that early aggressive behaviour predicts antisocial behaviour in adolescent; for example, Nagin \& Tremblay (2001) reported that children who displayed high levels of aggression in kindergarten were identified as exhibiting chronic violence in older age. In their study, Nagin \& Tremblay (2001) also found that high levels in hyperactivity and opposition in kindergarten were powerful predictors of high aggression. And Farrington and colleagues (2008) have indicated that violence in childhood or adolescence is the best predictors of future violence. Thus Tremblay and LeMarquand (2001) and 
Bor and colleagues (2001) affirm that display of aggressive behaviour in children of 5 years of age strongly predicts antisocial behaviour among in adolescents. Earlier studies in aggression indicate that early onset of aggression is associated with serious and chronic offending among young people and young adults.

Currently there is an alarming increase of youth involved in delinquency and criminal action in urban and sub urban areas of Malaysia; and this paper aimed to identify the most common delinquent actions, measure the level of aggressive and delinquent behaviour and examine the associations of aggressive and delinquent behaviour individual with demographic factors and individual characteristics among Malaysians youth offenders.

\section{Method}

\subsection{Procedure}

The data used in this paper was obtained from a larger study designed to identify patterns of delinquency behaviour among teenagers and young people (15-40 years old) in Malaysia, and examine the psychosocial issues linked to this behaviour patterns. The main project used both qualitative and quantitative research methods and analysis. Data was elicited using Focus Group Discussions and a questionnaire. However, this paper will highlight the findings from the quantitative part of the project. The study was carried in Klang Valley; a metropolitan area which has a multi-ethnic population and in the past 10 years has experienced rapid urban development. Subjects for the quantitative study were selected using purposive sampling techniques; the sample was drawn from urban and rural areas in the Klang Valley. After identifying the potential participants, data was collected using a self-administrative questionnaire.

\subsection{Sample}

Respondents were selected using purposive sampling technique. The sample consisted of 270 high risk youth -adolescents and young people below 40 years old- living in Klang Valley. A total of 144 respondents were male (53.3\%) and 126 respondents were female (46.7\%); and $76.7 \%$ of the sample was in the 21 and 30 years old category (table 1).

\subsection{Measurements}

Data was collected using a self-administrative questionnaire that consisted of the following 8 sections: Socio-demographics, Self-worth, Religiosity, Family Relationships, Peer Relations, Delinquency Scale, and measurements of Aggressive Behaviour. For the purpose of this paper the demographic characteristics used were age, gender, ethnicity and religion. The outcome variables used for this paper were:

- Delinquency behaviour, consisting of 20 items that measure a 5-point Likert scale the frequency in which delinquent acts were committed by the respondent, ranging from "never " to" Too often ". The higher the score obtained, the higher delinquent behaviour committed by the respondent.

- Aggressive Behaviour consisted of 14 items that measured the aggressiveness of respondents in a 5-point Likert scale ranging from "strongly disagree" to "strongly agree ". High scores indicate high aggressiveness.

Along with the description of subjects, give the mended size of the sample and number of individuals meant to be in each condition if separate conditions were used. State whether the achieved sample differed in known ways from the target population. Conclusions and interpretations should not go beyond what the sample would warrant.

\section{Results}

Table 1. Demographic characteristics

\begin{tabular}{llll}
\hline & & $\mathrm{N}$ & $\%$ \\
\hline \multirow{2}{*}{ Gender } & Female & 126 & 46.75 \\
\multirow{2}{*}{ Age } & Male & 144 & 53.3 \\
& $15-20$ years old & 53 & 19.6 \\
Ethnicity & $21-30$ years old & 207 & 76.7 \\
& 31-40 years old & 10 & 3.7 \\
& Malay & 130 & 48.1 \\
Religion & Chinese & 85 & 31.5 \\
& Indian & 55 & 20.4 \\
& Buddhist & 48 & 17.8 \\
& Christians & 50 & 18.5 \\
& Hindu & 39 & 14.4 \\
\hline
\end{tabular}


The ethnic and religion distribution of the sample is in accordance of that of the general population. Thus, even though the sampling method was purposive; we can say that it can indicate the general situation investigated. Interestingly, the descriptive analysis summarized in Table 1 indicated an almost even gender distribution in the sample of high risk youth, with $46 \%$ of the participants being female and the remaining $53.3 \%$ being male.

The frequency analysis presented in table 2 indicates that although the sample consisted of high high-risk youth, majority of them scored low in delinquent behaviour. However, $68 \%$ of the sample exhibited moderate levels of aggressive behavior.

Table 2. Levels of delinquency behaviour and aggressive behaviour

\begin{tabular}{llllll}
\hline & \multicolumn{2}{l}{ Delinquency behaviour } & & \multicolumn{2}{l}{ Aggressive behaviour } \\
& Frequency & Percentage (\%) & & Frequency & Percentage (\%) \\
\hline Low & 246 & 91.1 & Low & 45 & 16.7 \\
Moderate & 19 & 7.0 & Moderate & 185 & 68.5 \\
High & 5 & 1.9 & High & 40 & 14.8 \\
Total & 270 & - & Total & 270 & 100.0 \\
\hline
\end{tabular}

Table 3 summarizes the most common delinquency behaviour among Malaysian youth. Among Muslim youth 'leaving the prayer' and 'not completing the fasting' were the most reported, but the rest of the listed delinquency behaviour were reported by all participants, regardless their age, gender or religion.

Table 3. Types of reported youth delinquent behaviour in Malaysia

\begin{tabular}{lll}
\hline Types Delinquent behaviour & & \\
\hline Leaving the prayer & Quarrelling & Throwing objects at people \\
Not completing the fasting & Using Drugs & Selling stolen goods \\
Premarital sexual intercourse & Hurting others & Violates honour \\
Drinking alcoholic beverages & Stealing & Broke into homes/building \\
Watching pornographic films & Damage to public properties & Glue sniffing \\
Fighting with parents & Buying stolen goods & Hit or physical assaulted parents \\
Driving without a license & Carrying weapon & \\
\hline
\end{tabular}

Using frequency analysis, Chi Square $\left(\mathrm{X}^{2}\right)$ the significant associations between demographic characteristics and levels of both delinquency and aggressive behaviour were examined. The results indicate significant associations between delinquency behaviour levels with both age and ethnicity; but no significant associations with gender or religion.

Table 4. Delinquency and aggressive behaviour by age group

\begin{tabular}{lllllllll}
\hline & \multicolumn{3}{l}{ Levels of Delinquency Behaviour* } & \multicolumn{5}{l}{ Level of Aggressive Behaviour** } \\
& \multicolumn{2}{l}{$\left(X^{2}(4)=20.84 ; p<0.001\right)$} & \multicolumn{5}{c}{ X2 $(4)=16.81 ; \mathrm{p}=0.002$} \\
& Low & Moderate & High & Total & & Low & Moderate & High \\
\hline $15-20$ & $44(17.9 \%)^{*}$ & $8(42.1 \%)^{*}$ & 1 & 53 & $15-20$ & $6(11.3 \%)^{*}$ & $31(58.5 \%)^{*}$ & $16(30.2 \%)^{*}$ \\
$21-30$ & $196(79.7 \%) *$ & $8(42.1 \%)^{*}$ & 3 & 207 & $21-30$ & $39(18.8 \%)^{*}$ & $144(69.6 \%)^{*}$ & $24(11.6 \%)^{*}$ \\
$31-40$ & $6(2.4 \%) *$ & $3(15.8 \%)^{*}$ & 1 & 10 & $31-40$ & 0 & $10(100 \%)^{*}$ & 0 \\
Total & 246 & 19 & 5 & 270 & Total & 45 & 185 & 40 \\
\hline
\end{tabular}

Note: $* \%$ within Level of Delinquency Behaviour; $* * \%$ within age category

The results presented in table 4 , show that those $79.7 \%$ of those with low levels of delinquency behaviour were in the age group 21-30, while percentages of those who exhibit moderate levels were in the 15-20 and 21-30 age categories, however very few, only 5 participants, exhibit high levels of delinquency behaviour $\left(X^{2}(4)=20.84\right.$; 
$p<0.001)$. When looking within each of the age categories it can be observe that in the $15-20$ years old categories $58.5 \%$ reported moderated levels of aggressive behaviour and $30.2 \%$ of them reported high levels of aggressive behaviour. While in the 21-30 years old categories $69.6 \%$ exhibit moderate levels and $11.6 \%$ high levels of aggressive behaviour and the 31-40 age group all exhibit moderated levels of aggressive behaviour. In other words, being older was associated with moderate levels of aggressive behaviour $\left(X^{2}(4)=16.81 ; p\right.$ $=0.002$ ).

Table 5 . Delinquency and aggressive behaviour by ethnicity

\begin{tabular}{|c|c|c|c|c|c|c|c|c|}
\hline & \multicolumn{4}{|c|}{$\begin{array}{l}\text { Levels of Delinquency Behaviour* } \\
\left.X^{2}(4)=10.51 ; p=0.03\right)\end{array}$} & \multicolumn{4}{|c|}{$\begin{array}{l}\text { Level of Aggressive Behaviour** } \\
X^{2}(4)=25.74 ; p<0.001\end{array}$} \\
\hline & Low & Moderate & High & total & & Low & Moderate & High \\
\hline Malay & $116(47.2 \%)$ & $13(68.4 \%)$ & 1 & 130 & Malay & $33(73.3 \%)$ & $93(47.45 \%)$ & $4(21.05 \%)$ \\
\hline Chinese & $78(31.7 \%)$ & $6(31.6 \%)$ & 1 & 85 & Chinese & $2(4.44 \%)$ & $65(33.16)$ & $8(42.11 \%)$ \\
\hline Indian & $52(21.1 \%)$ & 0 & 3 & 55 & Indian & $10(22.22 \%)$ & $38(19.39 \%)$ & $7(36.84 \%)$ \\
\hline Total & 246 & 19 & 5 & 270 & Total & 45 & 196 & 19 \\
\hline
\end{tabular}

Note: $* \%$ within ethnic group; $* * \%$ within Level of Aggressive Behaviour

The results summarized in table 5 below, shows that more Malay and Chinese participants exhibit moderate levels of delinquency behaviour than Indian participants $\left(X^{2}(4)=10.51 ; p=0.033\right)$. The results also indicate that more Malay showed low levels of aggressive behaviour while more Chinese participants exhibit high levels of aggressive behaviour $\left(X^{2}(4)=25.74 ; p<0.001\right)$.

Table 6. Level of aggressive behaviour by gender

\begin{tabular}{lllll}
\hline Gender & \multicolumn{2}{l}{ Levels of Aggressive Behaviour } & \multicolumn{2}{l}{ Total } \\
& Low & Moderate & $11(27.5 \%)$ & 126 \\
\hline Female & $31(68.88 \%)$ & $84(45.41 .7 \%)$ & $29(72.5 \%)$ & 144 \\
Male & $14(31.11 \%)$ & $101(54.59 \%)$ & 40 & 270 \\
Total & 45 & 185 & & \\
\hline
\end{tabular}

Note: $\mathrm{X}^{2}(2)=14.951 ; \mathrm{p}=0.01 * \%$ within Level of Aggressive Behaviour

Table 6, above, shows that more male respondents exhibited both moderate and high levels of aggressive behaviour than female respondents $\left(X^{2}(2)=14.951 ; p=0.01\right)$.

\section{Discussion}

The study sought to measure the level of aggressive and delinquent behaviour among Malaysian youth that were already engaging in youth crime; and to examine the associations of aggressive and delinquent behaviour with demographic factors and individual characteristics (age, gender, ethnicity and religion). The sample consisted of at risk youth; that is young people that engage in juvenile crimes in urban and suburban areas of Malaysia. The descriptive analysis indicated that about $48 \%$ of the young people engaging in criminal and/or antisocial activities at the time the data was collected were Malay; $76.7 \%$ of the total sample were between 21 and 30 years old and $53.3 \%$ of the youth that took part of this study were male. The finding of this study reflect a positive image of young Malaysians, since the high risk youth that took part on the study displayed low levels of delinquency and moderate aggressive behaviour. Indicating that is room for rehabilitation using relevant re-education programs and positive leisure activities.

In line with Steinberg and Monahan (2007) and Moffitt (2006) the results indicate that being older was associated with low levels of delinquency behaviour, and with moderate levels of aggressive behaviour. While the young people in the age groups 15-20 years old and 21 and 30 years old tended to score moderate and high in aggressive behaviour; the older group of young people participating in this study exhibit low level of aggressive and delinquency behaviour. The fact that the older group of young people participating in this study exhibit low levels of aggressive and delinquency behaviour, might be due to the fact that they have reach maturity and have responsibility as emerging adults in Malaysian society-this findings are in line with the literature on youth 
development. However, these results might be underlining a gap in Malaysian youth research in assessing and understanding the difference needs and risk for those young people between 21 and 30 years old that engage in youth crime, and at risk and/or antisocial behaviour. Hence the lack of relevant and efficient intervention programs to address aggressive behaviour issues and risk factors in all the 3 different age groups of young Malaysians. Any preventive program intervention to address effectively youth delinquency and/or antisocial s behaviour needs to be age appropriate; thus the importance of understanding the risk factors are most relevant for each period of development (Herrenkohl, Maguin, Hill, Hawkins, Abbott, \& Catalano, 2000).

Religion was not found to be associated with religion was not associated to either levels of delinquency or aggressive behaviour, but ethnicity was associated with both. Although both Malay and Chinese at risk group show more moderate levels of delinquency behaviour than Indian participants; Chinese at risk youth reported higher levels of aggressive behaviour than the other ethnic groups. It is possible that the type of upbringing, the community dynamics and stress level experience by young people would give rise to opportunity for them to behave aggressively. However, to the authors' knowledge there are currently no empirical data in Malaysia to support or reject this hypothesis. Thus, in depth studies need to be conducted to investigate further the root cores of the issue of aggressive behaviour among these ethnic groups.

The results in this study indicated that level of aggressive behaviour was associated with gender. More male at risk youth respondents exhibited both moderate and high levels of aggressive behaviour than female at risk groups, but there were no gender associations with delinquency behaviour in this study. These results are in line with that of Rey and colleagues (2005); in their study they also found no gender differences among the group of young delinquents, but most male exhibit aggressive behaviour than female respondents. The association of aggressive behaviour with gender in our study might be explain by the fact that the aggressive behaviour measured in the study was overt rather relational aggression. The literature in aggression indicates that while boys are most luckily to engage in overt aggression, girls tend to display more relational aggression (e.g. Basow, Cahill, Phelan, Longshore, \& McGillicuddy-DeLisi, 2007; Miller-Ott \& Kelly, 2013)

Research suggests an association between leisure boredom and high-risk behaviours among young adults and adolescents (Patterson \& Pegg, 1999; Wegner \& Flisher, 2009; Caldwell \&d Smith, 1995; Newberry \& Duncan, 2001). For example authors suggest that adolescents and young adults who perceive their leisure to be unsatisfying may be at greater risk of engaging in risky activities (Yang \& Yoh 2005; Larson \& Richards, 1991) More specifically research indicate that young boys who experience high levels of leisure boredom and have a greater propensity to engage in antisocial or non-violent criminal behaviour (e.g. drinking, car/motor racing,) (Iso-Ahola \& Crowley, 1991). There also studies that suggest that antisocial behaviour in adolescent and young adults is associated with hedonistic values and a lack of interest in conventional values and social values (Romero, Sobral, Luengo, \& Marzoa, 2001); and with personality traits such as low straight forwardness, low compliance, and low deliberation (Miller, Lynam, \& Leukefeld, 2003)

The findings of this study revealed that intervention programs designed to reduce and or manage delinquency based on and aggressive behaviour should not only focused on young people between 15 and 20 years old; but that there is a need for programs targeting young adults in the age group of 21-30 years old since more people in this age group tended to score moderate and high in aggressive behaviour. It can be argued that these 21 to 30 years old young people might be exhibiting chronic aggressive behaviour.

There are challenges in attempting to address youth delinquency in Malaysia, according to anecdotal evidence these challenges might be related to the struggle of Malaysian youth with identity crisis, emotional stress and boredom. And according to qualitative research data from various youth studies carried out in Malaysia there seems to be a great need of youth programs that focus on soft skills development and of values and moral education. Therefore to address these challenges it is needed (1) a more thorough approach in understanding how identity crisis, emotional stress and boredom impact the way in which young Malaysians behave and interact with their community, and (2) preventive programs that combine competency skills, and moral values education. However, a better understanding of youth crime, delinquency and aggressive behaviour among Malaysian youth is crucial, and it is highly recommended that further study are carried out to obtain in-depth data in order to elicit relevant and contextual information about the factors, motives and impact associated to aggressive behaviour in Malaysian youth.

\section{Acknowledgments}

This project was sponsored by the Malaysian Ministry of Higher Education under the FRGS Scheme. 


\section{References}

Aaron, L., \& Dallaire, D. H. (2010). Parental incarceration and multiple risk experiences: Effects on family dynamics and children's delinquency. $J$ Youth Adolesce, 39(12), 1471-1484. http://dx.doi.org/10.1007/s 10964-009-9458-0

Achenbach, T. M. (1991). Manual for the Child Behavior Checklist/4-18 and 1991 Profile. Burlington, VT: University of Vermont Department of Psychiatry.

Achenbach. T. M., \& Edelbrock, C. (1981). Behavioral problems and competencies reported by parents of normal and disturbed children aged 4-16. Monographs of the Society for Research in Child Development, 46, 88. http://dx.doi.org/10.2307/1165983

Aguilar, B., \& Egeland, B. (2002). The development of delinquency. In N. J. Salkind (Ed.), Child Development: Macmillan Psychology Reference Series (Vol. 1, pp. 117, 119). Farmington Hills, MI: Macmillan Reference.

Atkins, M. S., \& Stoff, D. M. (1993). Instrumental and hostile aggression in childhood disruptive behavior disorders. Journal of Abnormal Child Psychology, 21, 165-178. http://dx.doi.org/10.1007/BF00911314

Bartol, C. R., \& Bartol, A. M. (2009). Juvenile Delinquency and antisocial behaviour: A developmental perspective (3th ed.) Pearson-Prentice-Hall.

Basow, S. A., Cahill, K. F., Phelan, J. E., Longshore, K., \& McGillicuddy-DeLisi, A. (2007). Perceptions Of Relational And Physical Aggression Among College Students: Effects Of Gender Of Perpetrator, Target, And Perceiver. Psychology of Women Quarterly, 31, 85-95. http://dx.doi.org/10.1111/j.1471-6402.2007. 00333.x

Bor, W., Najman, J. M., O'Callaghan, M., Williams, G. M., \& Anstey, K. (2001). Aggression and the development of delinquent behaviour in children. Trends and Issues in Crime and Criminal Justice, 207, $1-5$.

Brown, B. B., Mounts, N., Lamborn, S. D., \& Steinberg, L. (1993). Parenting practices and peer group affiliation in adolescence. Child Development, 63, 391-400. http://dx.doi.org/10.2307/1131263

Brown, S. (1998). Understanding Youth and Crime (Listening to youth?). Buckingham: Open University Press.

Buehler, C. (2006). Parents and Peers in Relation to Early Adolescent Problem Behavior. Journal of Marriage and Family, 68(1), 109-124. http://dx.doi.org/10.1111/j.1741-3737.2006.00237.x

Caldwell, L. L., Smith, E. A., \& Weissinger, E. (1992). The relationship of leisure activities and perceived health of college students. Loisir et Société/Society and Leisure, 15, 545-556. http://dx.doi.org/10.1080/07053 436.1992.10715431

Campbell, S. B. (1995). Behaviour problems in preschool children: A review of recent research. Journal of Child Psychology and Psychiatry, 36(1), 115-119. http://dx.doi.org/10.1111/j.1469-7610.1995.tb01657.x

Cauffman, E., Farruggia, S. P., \& Goldweber, A. (2008). Bad boys or bad parents: Relations to female juvenile delinquency. Journal of Research on Adolescence, 18, 699-712. http://dx.doi.org/10.1111/j.1532-7795. 2008.00577.x

Cauffman, E., Piquero, A. R., Kimonis, E., Steinberg, L., Chassin, L., \& Fagan, J. (2007). Legal, individual, and environmental predictors of court disposition in a sample of serious adolescent offenders. Law and Human Behavior, 31(6), 519-535. http://dx.doi.org/10.1007/s10979-006-9076-2

Collins, J., Noble, G., Poynting, S., \& Tabar, P. (2000). Kebabs, kids, cops \& crime: Youth, ethnicity \& crime. Sydney: Pluto Press.

Crick, N. R., \& Grotpeter, J. K. (1995). Relational aggression, gender, and social-psychological adjustment. Child Dev, 66(3), 710-722. http://dx.doi.org/10.2307/1131945

Day, D. M., \& Wanklyn, S. G. (2012). Identification and Operationalization of the Major Risk Factors for Antisocial and Delinquent Behaviour among Children and Youth. NCPC Research Report. Ottawa, ON: Public Safety Canada.

Din, W. G. W. (2000). Gangguan emosi dan kaitan dengan kenakalan remaja. Laporan penyelidikan yang tidak diterbitkan, Universiti Malaya.

Dishion, T. J., McCord, J., \& Poulin, F. (1999). When interventions harm: Peer groups and problem behaviour. American Psychologist 1999, 54, 755-764. http://dx.doi.org/10.1037/0003-066x.54.9.755 
Dodge, K. A. (1991). The structure and function of reactive and proactive aggression. In D. Pepler, \& K. Rubin (Eds.), The development and treatment of childhood aggression (pp. 201-218). Hillsdale, NJ: Erlbaum.

Dodge, K. A., \& Schwartz, D. (1997). Social information processing mechanisms in aggressive behavior. In D.M. Stoff, J. Breiling, \& J. Maser (Eds.), Handbook of Antisocial Behavior (pp. 171-180). New York: Wiley.

Dodge, K. A., Coie, J. D., \& Lynam, D. (2006). Aggression and antisocial behaviour in youth. In N. Eisenberg, W. Damon, \& R. M. Lerner (Eds.), Handbook of child psychology (6th ed., Vol. 3). Social, emotional and personality development (pp. 719-788). Hoboken, NJ: Wiley.

Eadie, T., \& Morley, R. (2003). Crime, Justice and Punishment. In J. Baldock et al. (Eds.), Social Policy (3rd ed.). Oxford: Oxford University Press.

Farrington, D. P. (1987). Implications of biological findings for criminological. In S. A. Mednick, T. E. Moffitt, \& S. A. Stack (Eds.), The Causes of Crime: New Biological Approaches (pp. 42-64). Cambridge: Cambridge University Press. http://dx.doi.org/10.1017/CBO9780511753282.005

Farrington, D. P. (1994). Early developmental prevention of juvenile delinquency. Criminal Behaviour and Mental Health, 4(3), 209-227.

Farrington, D. P. (2001). Predicting adult official and self-reported violence. In G. F. Pinard, \& L. Pagani (Eds.), Clinical assessment of dangerousness: Empirical contributions (pp. 66-88). New York: Cambridge University Press.

Farrington, D. P. (2002). Key Results from the First Forty Years of the Cambridge Study in Delinquent Development. In T. Thornberry, \& D. Krohn (Eds.), Taking Stock of Delinquency: An Overview of Findings from Contemporary Longitudinal Studies. New York: Plenum.

Farrington, D. P., Loeber, R., Jolliffe, D., \& Pardini, D. A. (2008). Promotive and risk processes at different life stages. In R. Loeber, D. P. Farrington, M. Stouthamer-Loeber, \& H. Raskin White (Eds.), Violence and Serious Theft: Development and Prediction from Childhood to Adulthood (pp. 169-230). New York: Routledge.

Ferris, C. F. E., \& Grisso, T. (1996). Understanding aggressive behavior in children. New York: New York Academy of Sciences.

Feshbach, S. (1970). Aggression. In P. Mussen (Ed.), Carmichaels' manual of child psychology (pp. 159-259). New York: Wiley.

Feshbach, S. (1971). Dynamics and morality of violence and aggression: Some psychological considerations. American Psychologist, 26, 281-292. http://dx.doi.org/10.1037/h0031219

Hartup, W. W., \& Stevens, N. (1999). Friendships and adaptation across the life span. Current Directions in Psychological Science, 8(3), 76-79. http://dx.doi.org/10.1017/CBO9780511499494

Haslinda, A., Gill, S. S., Nobaya, A., Zaid, A., \& Ghazali, S. (2009). Remaja dan budaya lumba haram di Lembah Klang. Malaysian Journal of Youth Studies, 1, 165-178. Retrieved from http://www.ippbm.gov.my/ index.php?option $=$ com_content\&view $=$ article\&id $=334 \&$ lang $=$ bm

Herrenkohl, T. I., Guo, J., Kosterman, R., Hawkins, J. D., Catalano, R. F., \& Smith, B. H. (2001). Early adolescent predictors of youth violence as mediators of childhood risks. Journal of Early Adolescence, 2(4), 447-469. http://dx.doi.org/10.1177/0272431601021004004

Herrenkohl, T. I., Maguin, E., Hill, K. G., Hawkins, J. D., Abbott, R. D., \& Catalano, R. F. (2000). Developmental risk factors for youth violence. Journal of Adolescent Health, 26, 176-186. http://dx.doi.org/ 10.1016/S1054-139X(99)00065-8

Holmes, E., Jones-Sanpei, H., \& Day, R. D. (2009). Adolescent outcome measures in the NLSY97 Family Process Dataset: Variation by race and socioeconomic conditions. Marriage and Family Review, 45. http://dx.doi.org/10.1080/01494920902828151

Huff, C., Widmer, M., McCoy, K., \& Hill, B. (2003). The influence of challenging outdoor recreation on parent-adolescent communication. Therapeutic Recreation Journal, 37(1), 18-37. Retrieved from http://www.bctra.org/wp-content/uploads/tr_journals/1024-4016-1-PB.pdf

Iso-Ahola, S. E., \& Weissinger E. (1990). Perceptions of boredom in leisure: Conceptualization, reliability and validity of the Leisure Boredom Scale. Journal of Leisure Research, 22, 1-17. Retrieved from http://psycnet. apa.org/psycinfo/1990-21429-001 
Kosterman, R., Hawkins, J. D., Spoth, R., Haggerty, K. P., \&d Zhu, K. (1997). Effects of a preventive parent training intervention on observed family interactions: Proximal outcomes from preparing for the drug free years. J Community Psychol, 25(4), 337-352. http://dx.doi.org/10.1002/(SICI)1520-6629(199707)25:4<337:: AID-JCOP3>3.0.CO;2-R

Laird, R. D., Pettit, G. S., Dodge, K. A., \& Bates, J. E. (2003). Change in parents' monitoring knowledge: Links with parenting, relationship quality, adolescent beliefs, and antisocial behaviour. Social Development, 12(3), 401-419. http://dx.doi.org/10.1111/1467-9507.00240

Larson, R. W., \& Richards, M. H. (1991). Boredom in the middle school years: blaming schools versus blaming students. American Journal of Education, 99, 418-443. http://dx.doi.org/10.1086/443992

Leiber, M. J., \& Johnson, J. D. (2008). Being young and black: What are their effects on juvenile justice decision making? Crime \& Delinquency, 54, 560-581. http://dx.doi.org/10.1177/0011128707308857

Liu, J. (2004). Childhood Externalizing Behavior: Theory and Implications. Journal of Child and Adolescent Psychiatric Nursing, 17, 93-103. http://dx.doi.org/10.1111/j.1744-6171.2004.tb00003.x

Livingston, M., Stewart, A., Allard, T., \& Ogilvie, J. (2008). Understanding juvenile offending trajectories. The Australian and New Zealand. Journal of Criminology, 41, 345-363. http://dx.doi.org/10.1375/acri.41.3.345

Lloyd, J. J., \& Anthony, J. C. (2003). Hanging out with the wrong crowd: How much difference can parents make in an urban environment. J Urban Health, 80(3), 383-399. http://dx.doi.org/10.1093/jurban/jtg043

Loeber, R., Green, S. M., \& Lahey, B. B. (2003). Risk factors for adult antisocial personality. In D. P. Farrington, \& J. W. CoidW (Eds.), Early Prevention of Adult Antisocial Behaviour (pp. 79-108). Cambridge, England: Cambridge University Press.

Loeber, R., Stouthamer-Loeber, M., Van Kammen, W. B., \& Farrington, D. P. (1991). Initiation, escalation and desistance in juvenile offending and their correlates. Journal of Criminal Law and Criminology, 82, 36-82. http://dx.doi.org/10.2307/1143789

Lynam, D. R., Miller, D. J., Vachon, D., Loeber, R., \& Stouthamer-Loeber, M. (2009). Psychopathy in adolescence predicts official reports of offending in adulthood. Youth Violence and Juvenile Justice, 7, 189-207. http://dx.doi.org/10.1177/1541204009333797

Mannes, M., Roehlkepartain, E. C., \& Benson, P. L. (2005). Unleashing the power of community to strengthen the well-being of children, youth, and families: An asset-building approach. Child Welfare, 84(2), 233-250. Retrieved from http://europepmc.org/abstract/MED/15828410

Marshall, J. (2006). Juvenile offending trajectories: A South Australian study. Adelaide, Australia: South Australia Department of Justice, Office of Crime Statistics and Research. Retrieved from http://www98. griffith.edu.au/dspace/bitstream/handle/10072/22981/52824_1.pdf?sequence=1

McCord, J., Widom, C. S., \& Crowell, N. A. (Eds.). (2001). Juvenile crime, juvenile justice. Washington, DC: National Academy Press.

Meloy, J. R. (1988). The psychopathic mind: Origins, dynamics, and treatment. Northvale, NJ: Jason Aronson.

Miller, J. D., Lynam D., \& Leukefeld C. (2003). Examining antisocial behaviour through the lens of the five factors model of personality. Aggressive Behavior, 29(6), 497-514. http://dx.doi.org/10.1002/ab.10064t

Miller-Ott, Aimee, E., Kelly, \& Lynne. (2013). Mean Girls in College: An Analysis of How College Women Communicatively Construct and Account for Relational Aggression Women's Studies in Communication, 36(3). Retrieved from https://www.questia.com/library/journal/1G1-353995077/mean-girls-in-college-an -analysis-of-how-college

Moffitt, T. E. (1993). Adolescent-limited and life-course-persistent antisocial behavior: A developmental taxonomy. Psychological Review, 100(4), 674-701. http://dx.doi.org/10.1037/0033-295X.100.4.674

Moffitt, T. E. (2006). Life-course persistent versus adolescence-limited antisocial behavior. In D. Cicchetti, \& D. J. Cohen (Eds.), Developmental Psychopathology: Risk, disorder, and adaptation (2nd ed., pp. 570-598). New York: Wiley.

Monahan, K., Steinberg, L., \& Cauffman, E. (2009). Affiliation with antisocial peers, susceptibility to peer influence, and desistance from antisocial behaviour during the transition to adulthood. Developmental Psychology, 45, 1520-1530. http://dx.doi.org/10.1037/a0017417

Muhaini, S. H. (1992). Jenayah remaha: Masalah dan penyelesaiannya, satu kajian di Sarikei, Sarawak. Latihan 
Ilmiah yang tidak diterbitkan, Universiti Malaya.

Nagin, D. S., Farrington, D. P., \& Moffitt, T. E. (1995). Life-course trajectories of different types of offenders. Criminology, 33, 111-140. http://dx.doi.org/10.1111/j.1745-9125.1995.tb01173.x

Nagin, D., \& Tremblay, R. E. (1999). Trajectories of boys' physical aggression, opposition, and hyperactivity on the path to physically violent and nonviolent juvenile delinquency. Child Development, 70, 1181-1196. http://dx.doi.org/10.1111/1467-8624.00086

Newberry, A. L., \& Duncan, R. D. (2001). Roles of boredom and life goals in juvenile delinquency. Journal of Applied Social Psychology, 31, 527-541. http://dx.doi.org/10.1111/j.1559-1816.2001.tb02054.x

Patterson, G. R., DeBaryshe, B. D., \& Ramsay, E. (1989). A developmental perspective on antisocial behaviour. American Psychologist, 44, 329-335. http://dx.doi.org/10.1037/0003-066X.44.2.329

Patterson, I., \& Pegg, S. (1999). Nothing to do. The relationship between "leisure boredom" and alcohol and drug addiction: Is there a link to youth suicide in rural Australia? Youth Studies Australia, 18(2), 24-28.

Piquero, A. R., Farrington, D. P., \& Blumstein, A. (2007). Key issues in criminal career research: New analyses of the Cambridge Study in Delinquent Development. Cambridge, UK: Cambridge University Press.

Raman, A. M. I. (1999). Delinquency among students at a private institution of higher learning: A case study. Master Thesis, University of Malaya, Malaysia.

Rey, J. M., Sawyer, M. G., \& Prior, M. R. (2005). Similarities and differences between aggressive and delinquent children and adolescents in a national sample. Australian and New Zealand Journal of Psychiatry, 39(5). http://dx.doi.org/10.1080/j.1440-1614.2005.01583.x

Romero, E., Luengo, M., \& Sobral, J. (2001). Personality and antisocial behaviour: Study of temperamental dimensions. Personality and Individual Differences, 31(3), 329-348. http://dx.doi.org/10.1016/S0191-8869 (00)00139-2

Schulenberg, J. E., \& Zarrett, N. R. (2006). Mental health during emerging adulthood: Continuity and discontinuity in courses, causes, and functions. In J. J. Arnett, \& J. L. Tanner (Eds.), Emerging adults in America: Coming of age in the twenty-first century (pp. 135-172). Washington, D.C.: American Psychological Association. http://dx.doi.org/10.1037/11381-006

Shader, M. (2003). Risk factors for delinquency: An overview. Office of Juvenile Justice and Delinquency Prevention. Washington, DC. Retrieved from https://www.ncjrs.gov/pdffiles1/ojjdp/frd030127.pdf

Siegel, L. J., \& Welsh, B. C. (2005). Juvenile Delinquency: The core. Belmont, CA: Wadsworth.

Simons, R. L., Chao, W., Conger, R. D., \& Elder, G. H. (2001). Quality of Parenting as Mediator of the Effect of Childhood Defiance on Adolescent Friendship Choices and Delinquency: A Growth Curve Analysis. Journal of Marriage and Family, 63, 63-79. http://dx.doi.org/10.1111/j.1741-3737.2001.00063.x

Sprott, J., \& Doob, A. (2003). Justice for girls? Stability and change in the youth justice systems of the United States and Canada. Chicago, IL: University of Chicago Press.

Steffensmeier, D., Schwartz, J., Zhong, H., \& Ackerman, J. (2005). An Assessment of Recent Trends in Girls' Violence Using Diverse Longitudinal Sources: Is The Gender Gap Closing? Criminology, 43(2), 355-406. http://dx.doi.org/10.1111/j.0011-1348.2005.00011.x

Steinberg, L., \& Monahan, K. C. (2007). Age differences in resistance to peer influence. Developmental Psychology, 43(6), 1531-1543. http://dx.doi.org/10.1037/0012-1649.43.6.1531

Thornberry, T. P. (1998). Membership in youth gangs and involvement in serious and violent offending. In R. Loeber, \& D. P. Farrington (Eds.), Serious and violent juvenile offenders: Risk factors and successful interventions (pp. 147-166). Newbury Park, CA: Sage.

Tolan, P. H., \& Thomas, P. (1995). The implications of age of onset for delinquency risk: II. Longitudinal data. Journal of Abnormal Child Psychology, 23, 157-181. http://dx.doi.org/10.1007/BF01447087

Tolan, P. H., Gorman-Smith, D., \& Henry, D. B. (2003). The developmental ecology of urban males' youth violence. Developmental Psychology, 39(2), 274-291. http://dx.doi.org/10.1037/0012-1649.39.2.274

Tolan, P. H., Sherrod, L., Gorman-Smith, D., \& Henry, D. (2003). Building protection, support, and opportunity for inner-city youth and their families. In K. Maton, B. Leadbeater, \& A. Solaraz (Eds.), Positive youth development: Research and policy. Washington, DC: American Psychological Assoc. 
Tremblay, R. E., \& LeMarquand, D. (2001). Individual risk and protective factors. In R. Loeber, \& D. P. Farrington (Eds.), Child delinquents: Development, intervention, and service need (pp. 137-164). Thousand Oaks, CA: Sage Publications. http://dx.doi.org/10.4135/9781452229089.n7

Vitaro, F., Tremblay, R. E., Kerr, M., Pagani, L., \& Bukowski, W. M. (1997). Disruptiveness, Friends' Characteristics, and Delinquency in Early Adolescence: A Test of Two Competing Models of Development. Child Development, 68, 676-689. http://dx.doi.org/10.2307/1132118

Walklate, S. (2003). Understanding Criminology-Current Theoretical Debates (2nd ed.). Maidenhead: Open University Press.

Wasserman, G. A., \& Miller, L. S. (1998). The prevention of serious and violent juvenile offending. In R. Loeber, \& D. Farrington (Eds.), Serious and Violent Juvenile Offenders: Risk Factors and Successful Interventions (pp. 197-247). Thousand Oaks: Sage Publications Inc.

Wegner, L., \& Flisher, A. J. (2009). Leisure boredom and adolescent risk behaviour: A systematic literature review. Journal of Child and Adolescent Mental Health, 21(1), 1-28. http://dx.doi.org/10.2989/JCAMH. 2009.21.1.4.806

Yang, H., \& Yoh, T. (2005). The relationship between free-time boredom and aggressive behavioral tendencies among college students with disabilities. American Journal of Recreation Therapy, 4, 11-16.

Yessine, A. K., \& Bonta, J. (2009). The offending trajectories of youthful Aboriginal offenders. Canadian Journal of Criminology and Criminal Justice, 51(4), 435-472. http://dx.doi.org/10.3138/cjccj.51.4.435

\section{Copyrights}

Copyright for this article is retained by the author(s), with first publication rights granted to the journal.

This is an open-access article distributed under the terms and conditions of the Creative Commons Attribution license (http://creativecommons.org/licenses/by/3.0/). 